\title{
微視損傷進展を考慮した低合金鋼溶接継手のクリープ損傷評価法の提案
}

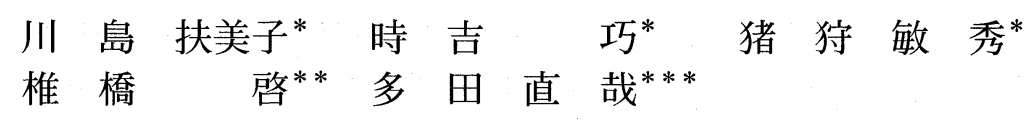

\section{A Proposal on Creep Damage Analysis of Welded Joint of Low-Alloy Steel Considering Microscopic Damage Progress}

\author{
by \\ Fumiko Kawashima ${ }^{*}$, Takumi TokIyoshi ${ }^{*}$, Toshihide IGARI ${ }^{*}$, \\ Akira SHIIBASHI $^{* *}$ and Naoya TADA ${ }^{* * *}$
}

\begin{abstract}
Creep damage analysis method of welded joint on the basis of the random fracture resistance model was proposed and was applied to the creep damage evaluation of welded joint of low alloy steel. Firstly a random fracture resistance of grain boundaries, an initiation and a growth driving forces of small defects, which were necessary in the above model, were determined considering the stress-dependent damage progress of the fine-grain $\mathrm{HAZ}$ material of $21 / 4 \mathrm{Cr}$-1Mo steel. Secondly a procedure combining both the stress distribution in the welded joint and the random fracture resistance model was concretely proposed and was applied to the creep damage evaluation of the model test and the actual power piping. Experimental results of both the time history and the distribution of the number density of small defects in the welded joint were successfully reproduced by the proposed method.
\end{abstract}

Key words : Creep, Damage, Small defect, Welded joint, Type IV, 21/4Cr-1Mo steel

1 はじめに

経年火力プラント高温大径配管溶接部の余寿命評価に 打いては, 溶接熱影響部（以下, HAZ と略す）の肉厚内 部から発生および成長するクリープ損傷の定量評価が重 要である，低合金鋼の HAZ は溶接金属側の粗粒域と母材 側の細粒域より成り，粗粒域でのクリープ損傷はType III 損傷, 細粒域での損傷は Type IV 損傷と呼ばれている.

本報が対象とする $21 / 4 \mathrm{Cr}-1 \mathrm{Mo}$ 鋼 HAZ 細粒域の Type IV 損傷では, HAZ 細粒域の板厚内部の方向に応力分布 があるため，主として寿命中期以降に，板厚内部の高応 力部に打いて，一結晶粒程度の大きさ，すなわち，最大 $10 \mu \mathrm{m}$ 程度の多数の微小久陥が発生する. 損傷が進行し, 寿命末期になると, この高応力部では, それらが合体し， 長さが $0.1 \mathrm{~mm} \sim 1 \mathrm{~mm}$ 程度の複数のき裂状欠陥となる. 主蒸気管のような $100 \mathrm{~mm}$ を越える厚肉管の場合, 板厚 内部にこのような複数のき裂状欠陥が検出されても，元 の板厚方向の長さによっては最終破断までは十分な時間 がある場合が多く，余寿命評価の観点からは，き裂状欠 陷の成長過程の評価も重要である.

一般に, 高温における材料の損傷形態は, 材料中の任 意の場所に多数の微小欠陥が次々と発生することが多く, ${ }^{2)}$ ここではこの損傷形態を「多場所発生型」と呼ぶこと にする。 この多場所発生型損傷は，大きく二つに分類で き, 材料中に多数の欠陥が発生し，元れらの合体を伴う
成長が寿命を支配する「欠陥発生型」と，発生する欠陥 の個数がそれほど多くなく，発生した欠陥の成長が寿命 を支配する「欠陥成長型」に分けられる. ${ }^{2)}$ Type $\mathrm{IV}$ 損傷は 基本的には前者に該当することになるが，部材中に応力 分布があるため，分類も簡単ではない，例えば，部材中 の応力が高い領域に欠陥発生型損傷が生じても，その領 域内に発生した欠陥の一部が成長・合体し，その領域を 逸脱するほどに大きくなると，その主欠陥の成長が寿命 を支配することになる。言い換えると，同一部材中にお いて久陷発生型から久陥成長型への遷移が生じることに なる.

現状の余寿命診断基準 ${ }^{3)}$ では, Type IV 損傷に対し， MLAS 法 (組織対比法) $\left.{ }^{3)}, 4\right)$ と破壊力学的き裂進展評価 を併用している．MLAS 法では，実体配管の溶接 HAZ 表面からレプリカを採取し，それを光学顕微鏡および走 査型電子顕微鏡で観察する. 両顕微鏡による組織観察の 結果と微小久陷個数密度の測定結果に基づき，余寿命が 評価されている。一方，破壊力学的き裂進展評価では， 超音波の回折を利用した TOFD 法で板厚内部の高応力部 でのき裂状欠陥の集合を検出し，これを単一の巨視き裂 に近似して， $C^{*}$ パラメータによるクリープき裂進展評価 を行っている。しかしながら, 多場所発生型損傷に対し, 単一の巨視き裂に対する破壊力学手法を用いることの妥 当性は明確にされていない。したがって，損傷実態を的

$\dagger \quad$ 原稿受理 $\quad$ 平成 14 年 5 月 10 日 Received May 10, 2002

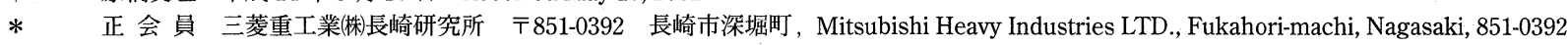

** 三菱重工業㑣ホホイラ技術部厂220-8401 横浜市西区みなとみらい, Mitsubishi Heavy Industries LTD., Nishi-ku, Yokohama, 220-8401

$* * *$ 正会員 岡山大学大学院自然科学研究科 $\overline{7} 700-8530$ 岡山市津島中, Graduate School of Natural Sci. and Tech., Okayama Univ., Tsushimanaka, Okayama, $700-8530$ 
確に表現し，かつ，MLAS 法およびTOFD 法から得られ る観察・測定結果を有効に利用する新たな余寿命評価法 が要求されている.

多場所発生型損傷の解析手法としては粒界破壊抵抗分 布モデル ${ }^{5}$ が提案されており，SUS304 の単軸クリープ疲 労損傷についてその有効性が示されている。このモデル は，応力分布の存在など負荷条件が場所によって変わる 場合や，同一場所における負荷条件が時間とともに変化 する場合のいずれにも基本的に対応できるが，それを実 際に溶接継手等の応力分布を有する部材のクリープ損傷 に適用した例はない。

本報では, $21 / 4 \mathrm{Cr}-1 \mathrm{Mo}$ 鋼の溶接継手 $\mathrm{HAZ}$ 細粒域での クリープ損傷に対する粒界破壊抵抗分布モデルの適用性 を検討するため，まず，粒界破壊抵抗分布モデルに基づ いて損傷解析シミュレーションを実施する際に必要な材 料特性の推定方法を提案した，次に，大型の溶接継手試 験体に対して, FEM クリープ解析から求めた応力分布 と損傷解析シミュレーションを組み合わせ, 溶接継手 $\mathrm{HAZ}$ 細粒域内のクリープ損傷を再現し, 観察結果との比 較を行った。ささらに, 実用温度域での大径配管溶接継手 の損傷分布計測結果との比較を行い，提案手法の実用性 を示した。

\section{2 粒界破壊抵抗分布モデルの低合金鋼への適用法}

\section{$2 \cdot 1$ 粒界破壊抵抗分布モデルの概要}

本モデルは, 多場所発生型クリープ疲労損傷の解析法 として提案され ${ }^{5)}$ SUS304 鋼の一様単軸引張り圧縮クリ ープ疲労条件下の損傷解析シミュレーションに用いられ ている. ${ }^{2), 5), 6)}$ 本モデルは, 久陷の分布に関する解析シミ ユレーション結果が, 実際の観察や非破壊的な推定結果 と一致するように駆動力を決定するところに特徴がある ため, 欠陥の発生や成長に関して詳細なメカニズムが明 確でなくても適用が可能である. 本論文で取り扱う Type IV クリープ損傷へも基本的に本モデルは適用可能と考え られ，以下に具体的な適用法について説明する。

\section{$2 \cdot 2$ 低合金鋼への適用法}

Fig. 1 に，本報で用いた粒界破壊抵抗分布モデルの概 要を示す. Fig. 1 (a)に示すように，まず，対象となる微 小領域の結晶粒界モデルを作成する．図中に太線で評価 対象の結晶粒界線を示す。この線上の各結晶粒界は, そ
れぞれ，異なる粒界長さ $L$ と破壊抵抗 $R$ を持つ。結晶粒 界長さ $L$ および破壊抵抗 $R$ は粒界毎に異なるため, これ らの集合 $[L]$ および $[R]$ を確率分布として扱い, 分布形 を材料依存と考える．Rがゼロになった粒界は微小欠陥 になると考える.

Fig. 1 (b)に示すように，クリープ負荷により，破壊抵 抗 $R$ は単位時間当たり $F$ ずつ減少する. $F$ は微小欠陥の 発生駆動力であり, 温度杼よびこの位置での応力に依存 すると考える. Fig. 1 (c) および式 (1)に示すように, 微 小久陥が生じると，それに隣接する結晶粒界では破壊抵 抗が $(F+K a)$ ずつ減少する。ここで, $a$ は粒界に隣接す る微小久陥の長さ, また, $K$ は微小久陥の成長駆動力の 係数であり，温度と応力に依存すると考える．これにつ いては, 後で詳述する。

$$
\frac{d R}{d t}=-(F+K a)
$$

粒界破壊抵抗分布モデルによる解析に必要な材料特性

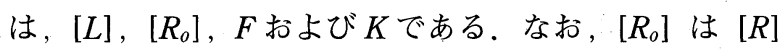
の初期值である.

クリープ損傷の温度 - 応力依存性は, 材料特性 $F$ およ び $K$ の温度・応力依存性により表現可能と考えられる. Table Iに, 本報で材料特性の推定に使用した試験，お よび損傷再現解析の対象とした試験の一覧を示す．材料 特性 $[L]$ および $\left[R_{o}\right]$ の推定には Table I の条件 (3) を, $F$ の推定にはTable Iの条件 (1) （3) を使用した。いず れの試験も，供試材は $21 / 4 \mathrm{Cr}-1 \mathrm{Mo}$ 鋼溶接部 $\mathrm{HAZ}$ 細粒 域である. Table Iの条件 (1)は, Plant Aにおいて, 841K で約 13 万時間使用された板厚 $31 \mathrm{~mm}$ の再熱蒸気管エル ボの腹側長手溶接 7 である. Table I の条件 (2) は, Plant B に打いて，848Kで約 15 万時間使用された板厚 $108 \mathrm{~mm}$ の主蒸気管エルボ腹側の長手溶接 ${ }^{8), 9)}$ である. Table Iの 条件 (3) は溶接継手モデル試験 ${ }^{10)}$ である. 溶接施工後に $\mathrm{HAZ}$ 細粒域を中心とし，断面が $40 \mathrm{~mm}$ 角になるように切 削加工している。試験温度は $898 \mathrm{~K}$, 負荷公称応力は $39 \mathrm{MPa}$ であり，破断時間は 8345 時間である.

\section{$2 \cdot 3$ 粒界破壊抵抗分布モデルの材料特性の推定}

$2 \cdot 3 \cdot 1$ 粒界長さ $[L]$ および粒界モデルの設定 粒 界長さ $[L]$ はTable Iの条件 (3) に示す試験体の実体組 織を光学顕微鏡で微視観察することにより推定した. 粒

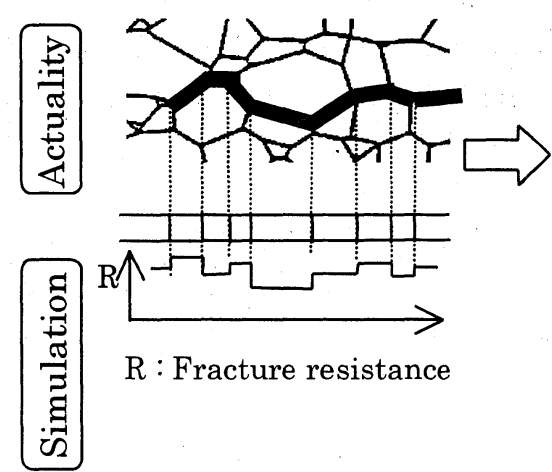

(a)

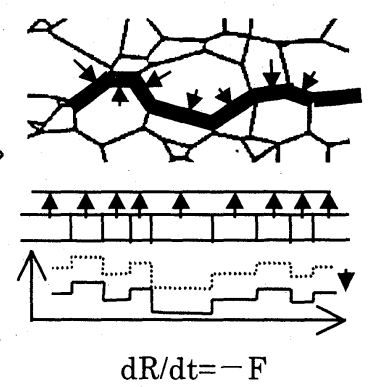

(b)

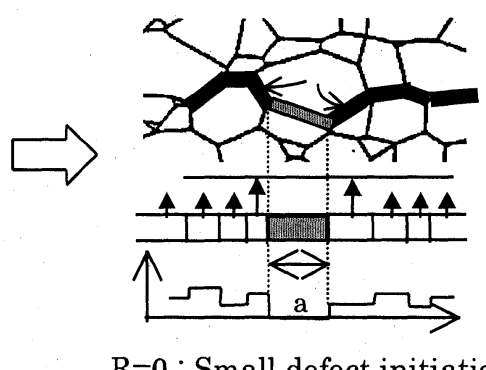

$\mathrm{R}=0$ : Small defect initiation $\mathrm{dR} / \mathrm{dt}=-(\mathrm{F}+\mathrm{Ka})$

(c)

Fig. 1. Scheme of random fracture resistance model. 
Table I . Conditions for parameter identification and damage simulation.

\begin{tabular}{|c|c|c|c|c|c|c|c|}
\hline \multirow{2}{*}{ No. } & Name & Temperature & \multirow{2}{*}{$\begin{array}{c}\text { Time } \\
(\mathrm{K})\end{array}$} & & \multicolumn{2}{|c|}{ Estimated parameter } & \multirow{2}{*}{$\begin{array}{c}\text { Damage } \\
\text { simulation }\end{array}$} \\
\hline$(1)$ & Plant A & 841 & 130000 & & & $\bigcirc$ & \\
\hline$(2)$ & Plant B & 848 & 150000 & & & $\bigcirc$ & $\bigcirc$ \\
\hline$(3)$ & $\begin{array}{c}\text { Model test } \\
\text { (Point C in Fig.5) }\end{array}$ & 898 & $\begin{array}{c}8345 \\
\text { (Time to rupture) }\end{array}$ & $\bigcirc$ & $\bigcirc$ & $\bigcirc$ & $\bigcirc$ \\
\hline
\end{tabular}

界長さ $[L]$ の分布は測定した結晶粒径の分布に等しいと 考え， $[L]$ を平均約 $10 \mu \mathrm{m} ，$ 標準偏差約 $5 \mu \mathrm{m}$ の正規分布 と設定した。

粒界モデルとしては，その部位での最大主応力に垂直 な複数の粒界を，直線上に並べた複数の平行な列を作製 し，列間の間隔は $[L]$ に従って定めた。この粒界モデル に扔いて, $1 \mathrm{~mm}^{2}$ 中に作製さ机る主応力方向に垂直な粒 界数の平均 $H$ は, 約 9070 個 $/ \mathrm{mm}^{2}$ である.

\section{$2 \cdot 3 \cdot 2$ 微小次俢発生駆動力 $\boldsymbol{F}$ および粒界破壊抵抗} $[R]$ の推定 $[R]$ の初期值 $\left[R_{0}\right]$ の分布形を，平均 0.5 の 正規分布と仮定し，クリープ試験における微小久陷個数 密度の時刻歷から $\left[R_{o}\right]$ の標準偏差および $F$ を推定する. $F$ は温度・応力に依存し，これらの条件が一定なクリー プ試験においては， $F$ は一定である。西る結晶粒界の破 壞抵抗 $R$ が時間経過に伴い低下寸る様子を，模式的に Fig. 2 に示す. 微小久陥に隣接しない結晶粒界の場合, この粒界の破壊抵抗 $R$ の減少は $F$ のみに依存する。なお 高温・高応力条件では $F$ が大きくなり，微小欠楩発生が 早まる.Rがゼロとなったときこの結晶粒界は微小久陥 となる。この結晶粒界が微小欠陥となる時刻 $t_{1}$ は, 式 (2)で表せる.

$$
t_{1}=\frac{R_{0}}{F}
$$

従って, 時刻 $t_{1}$ に打计る微小欠陥個数密度は, $R_{o} / F<t_{1}$ となる粒界の個数を表す。つまり, 微小久陷個数密度の 時刻歴は，集合 $\left[R_{o} / F\right]$ の累積分布を表す。攵らかじめ， $\left[R_{o}\right]$ の分布形を正規分布と仮定し，応力打よび温度が一 定であると考えると, $F$ も一定値となり， $\left[R_{o} / F\right]$ も正規 分布となる。

微小欠陥に隣接する粒界では, $R$ の減少は $F$ と $K$ の両 者に支配される，隣接する粒界で微小欠樎が発生する限

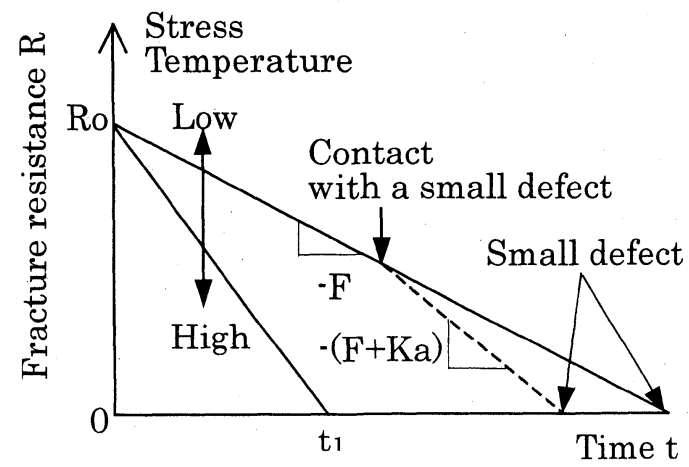

Fig. 2. Decrease of $R$ of one grain boundary.
界の時刻を $t_{2}$ とし，時刻 $t_{2}$ での微小欠陥個数密度を $N_{2}$ とする．時刻 $t_{2}$ 以降では，隣接する微小欠陷と $K$ の影響 により, 微小久樎個数密度の時刻歴と $\left[R_{o} / F\right]$ の分布形 は一致しない。このため, この方法で推定できるのは， 集合 $\left[R_{o} / F\right]$ の下限側 $N_{2} / H$ にあたる部分の分布形のみ であるが，集合全体が正規分布でありそのサイズが既知 である事から，下限側 $N_{2} / H$ の分布形から全体の分布形 を推定することができる。 また， $R_{0}$ の平均值を定めると， $\left[R_{o} / F\right]$ から， $\left[R_{o}\right]$ の分布形，および， $R_{o}$ の平均值に対 する比として， $F$ の值を推定することができる．本報で は, $\left[R_{0}\right]$ の平均を 0.5 と設定した.

なお, SUS304 のクリープ疲労損傷では $\left[R_{o}\right]$ を一様分 布と考えた ${ }^{5)}$ が，本材料では正規分布と考えた。これは， 後述の Fig. 7 に示寸様に, 微小久陥個数密度が主とし て，寿命の中期以降に増加するという本材料の特徴を反 映している。

具体的には, Table Iの条件（3）に示す試験に上記の 方法を適用し， $\left[R_{\theta}\right]$ 扎よびTable I の条件 (3) の温度お よび Fig. 5 中の Point $C$ 位置での応力に扎ける $F$ を推定 した．推定には，2つ以上の結晶粒界にわたる微小久陥 が発生する以前の，負荷初期段階 $(t / t r<50 \%)$ のデータ を使用した。ここで， $t$ および $\operatorname{tr}$ は，それ乤れ負荷時間 およびクリープ破断時間である.

$\left[R_{o}\right]$ が既知であれば，微小欠陥個数密度の時刻歴が 不明の場合でも，ある時刻での值のみから $F$ を推定する ことができる，元こで，Table Iの条件（3）から求めた $\left[R_{0}\right]$ を, HAZ 細粒域での代表值と考え, Table I の条 件 (1). (2) に示す実機使用材の損傷観察結果にも適用し て, Table Iの条件 (1) (2) の温度・応力条件での $F$ を推 定し，Fの応力依存性を考慮した. Plant Aについては 外表面の, また, Plant B については肉厚内部の, 応力 および微小欠陥個数密度から推定した.

$2 \cdot 3 \cdot 3$ 微小欠陥成長駆動力係数 $K$ の推定 クリー プが支配的な破壊の場合，一般に，粒界に存在する析出 物や段差, 粒界三重点等を起点として微小久陥（キャビ ティ）が発生し，それが粒界拡散によって成長する。ま た，拡散支配の成長では，欠陥の成長に伴い成長速度は 急激に減少することが知られている。一方，キャビティ がある大きさを越えるとその先端には応力特異場が形成 され，パラメータ等の破壞力学パラメータ支配の微小き

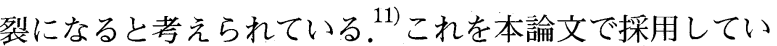
る粒界破壊抵抗分布モデルに打ける微小欠陥の成長駆動 力に置き換えて考えると，発生した微小久陥が小さい場 
合は，欠陥長さとともに減少するような駆動力を有し， 欠陥が大きく成長すると破壊力学的な駆動力に相当する 欠陥の長さに比例した駆動力を持つものと考えられる. しかしながら，拡散による成長と破壞力学的成長の区別, すなわち， 久陷先端の応力，ひずみ分布の相違を見るこ とは現時点では容易でなく, $21 / 4 \mathrm{Cr}-1 \mathrm{Mo}$ 鋼 HAZ 細粒域 での Type IV 損傷に扔いて実際に観察される微小久陥の 成長が，いずれに属するかを判別するのは容易ではない． したがって, 本論文では, 微小欠陥の発生およびその直 後の拡散支配の成長を発生の破壊駆動力 $F て ゙$, 欠陥が比 較的大きくなった場合に支配的となる破壊力学的な成長 の駆動力を $K a$ で与えることとする．拡散支配の成長を $K / a^{n}$ 等の形で縓密に取り扱うこともできるが，ここでは 実用性を考え，このようにした。

長さ $a$ の微小欠陥に隣接した粒界が, 微小時間 $d t$ 後 に微小欠陥になった場合, この粒界の破壊抵抗 $R_{0}$ は式 (3)で与えられる.

$$
R_{0}=d t(F+K a)
$$

この粒界の長さを $L$ とすると, $L$ は微小時間 $d t$ での微小 欠陥成長量であり, 成長速度 $\dot{a}$ は, 式 (4)で表される.

$$
\dot{a}=d a / d t=L / d t
$$

式 (3)と式 (4)を用いる事で, 式 (5)が得られる.

$$
\frac{K}{R_{0}}=\left\{1-\frac{F}{R_{0}} \frac{L}{\dot{a}}\right\} \frac{\dot{a}}{a L}
$$

$R_{o}$ としては集合 $\left[R_{o}\right]$ の平均值 0.5 を, $L$ としては $[L]$ の平均值を, また, $F$ としては $2 \cdot 3 \cdot 1$ 項で推定した值 を用い，無限体中の単一き裂に対する $C^{*}$ パラメータ ${ }^{12)}$ 打よび $a$ とC゙ パラメータの線形関係を仮定したき裂進展 速度式を用いることで, 式 (5)から $K$ を求めることとした.

\section{2 - 4 21/4Cr-1Mo 鋼 HAZ 細粒域の材料特性推定 結果}

以上の方法により推定した破壊抵抗の初期値 $\left[R_{o}\right]$, 微小欠陷発生駆動力 $F$ 打よび成長駆動力 $K$ を Fig. 3 (a) （c)に示す.

微小久陷発生駆動力 $F$ と作用応力は Fig. 3 (b) に示す ように, Larson Miller Parameter とよい相関を示してい る.ここで言う応力はビード形状も考えた板厚方向の局 所のものであり，また，実際の高温配管溶接部に負荷さ れる 60MPa 程度以下を対象としており，Larson Miller Parameter の定数としては $21 / 4 \mathrm{Cr}-1 \mathrm{Mo}$ 鋼母材の低応力側 での定数 ${ }^{13)}$ である 15.6 を用いている。 なお，図中 Plant

A, Plant B は, Table I 中の条件と同じである. Fig. 3

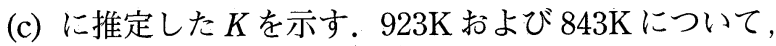
応力 $10 \sim 60 \mathrm{MPa}$ の範囲で推定した.

実際の高温配管溶接部の使用条件は $823 \sim 873 \mathrm{~K}$, $60 \mathrm{MPa}$ 以下であり，この条件では粒界クリープ破壊にな ると考学られ, ${ }^{14)}$ 寿命末期を除き $K a$ は $F$ に比較し十分小 さく，損傷進展は $F$ のみで表現できると考えられる.

\section{3 溶接継手のクリープ損傷進展評価への適用法}

大径配管溶接部には応力分布が存在する。例えば一様 材料から成る厚肉円筒が内圧を受ける場合の円周方向応 力は，弾性では円筒内面が高いが，Norton クリープ則に

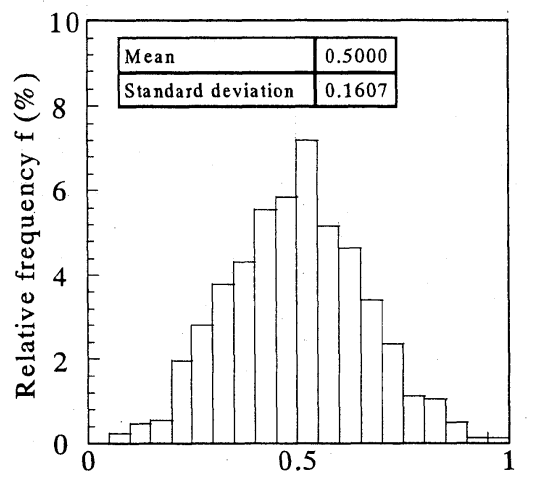

Fracture resistance of grain boundaries Ro

(a) Fracture resistance [Ro]

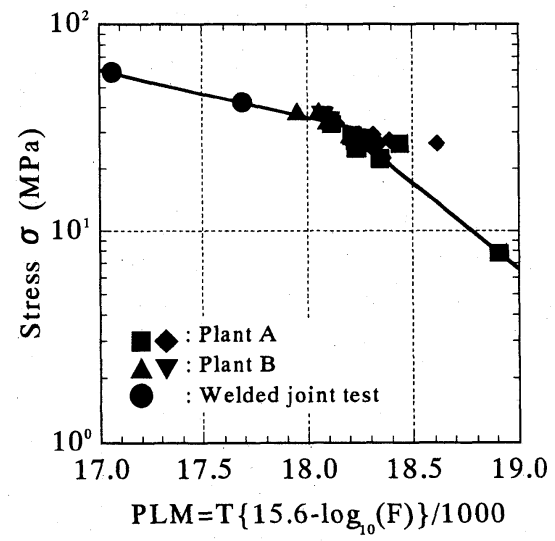

(b) Small defect initiation driving force $\mathrm{F}$

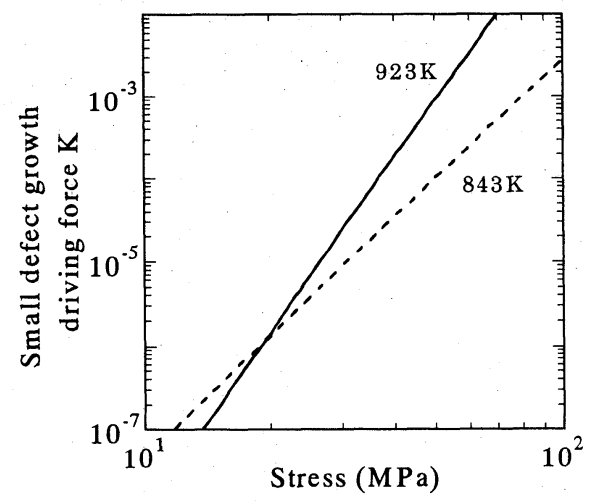

(c) Small defect growth driving force $\mathrm{K}$

Fig. 3. Estimated parameters for fine grain $\mathrm{HAZ}$ material.

従う構造的定常クリープ状態では, 円筒外表面が高いこ とが知られている．また，低合金鋼の溶接継手では，厚 さ $5 \mathrm{~mm}$ 程度の $\mathrm{HAZ}$ 細粒域は周囲の母材や溶接金属に比 べて硬さが低く，クリープ速度が速い。このため，HAZ 細粒域においては，配管表面に比べて，板厚内部では， 変形拘束により負の静水圧による 3 軸引張り状態になる

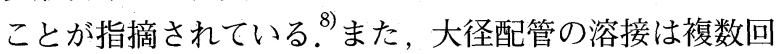
の溶接工程で行われるため, 板厚方向には, 溶接ビード 形状による凹凸があることも知られている。この材料不 連続部ではクリープ特性の違いにより応力ひずみ集中が 生じる。溶接継手の応力分布，特に HAZ 細粒域のクリ 一プ時の応力分布は, 上記の厚肉円筒, HAZ 細粒域のク リープ特性打よび溶接ビード形状による応力集中が重畳 したものとなっている.9 
本章では，溶接継手の FEM 弾性クリープ解析と粒界 破壊抵抗分布モデルを併用した溶接継手のクリープ損傷 解析法を提案する。粒界破壊抵抗分布モデルの材料特性 $F$ および $K$ としては前章で検討した応力依存性を考慮す るものとする.

Fig. 4 に，提案したクリープ損傷解析法の流れを示す. ステップ 1：まず，配管内外径，溶接開先形状および 溶接ビード形状など形状に関するデータを準備する，材 料特性として，母材，溶金，HAZ 細粒域および粗粒域の 縦弾性係数打よびクリープ速度を与える。本例ではクリ ープ速度は Norton 則の形で与えている。引き続き，こ れらを用いた FEM 弾性クリープ解析を行い, 構造的定 常状態での HAZ 細粒域の応力分布を求める.

ステップ 2 ：次に，結晶粒界モデルを作製する，HAZ 細粒域の結晶粒サイズのばらつきを考慮した一列の結晶

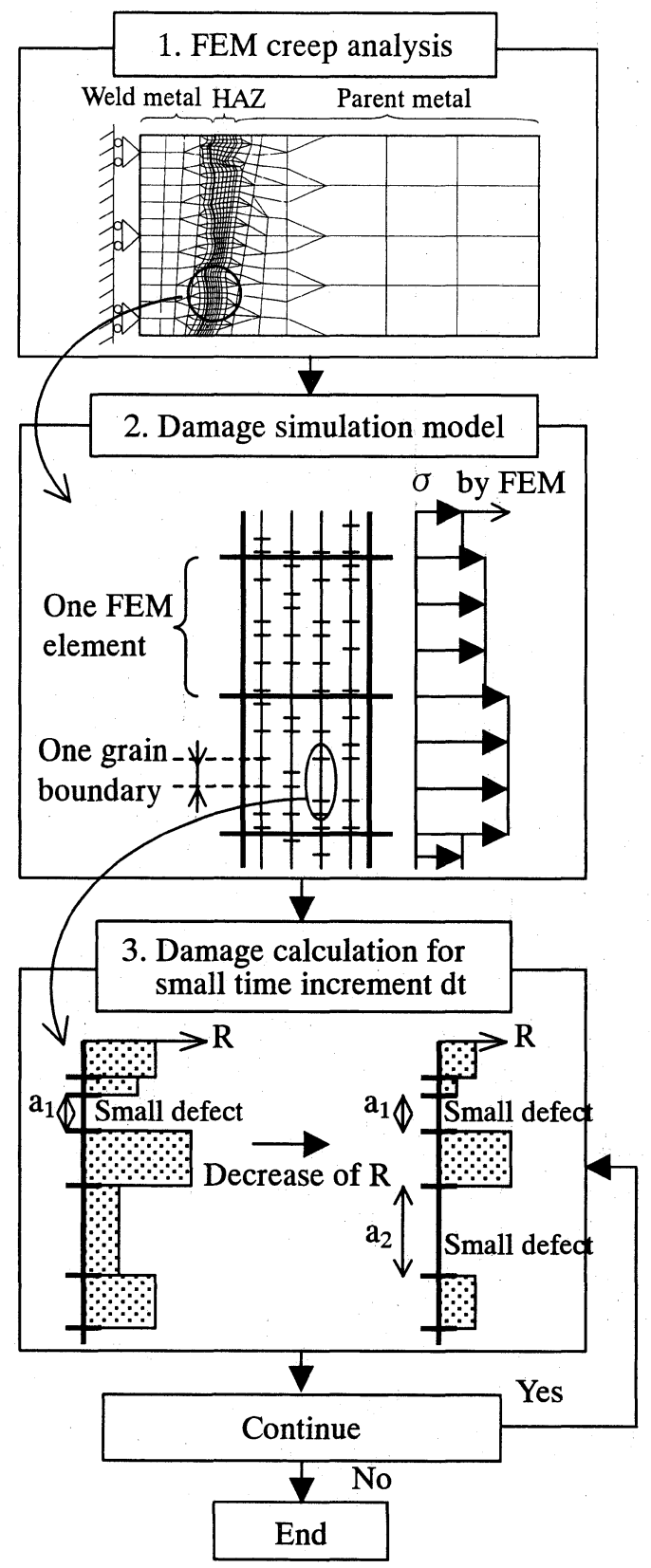

Fig. 4. Flow chart of simulation.
粒界モデルを，大径管溶接継手の管外面から管内面に渡 つて，複数の有限要素にまたがって設定する。結晶粒界 の長さや粒界の破壊抵抗のばらつきを考慮するため，複 数の平行な粒界モデルの列を作成する. 列間の間隔は, 粒界長さのばらつきに従って定めており，第 4 章での損 傷再現解析では，30 列の並行粒界モデルを作成した。

ステップ 3 ：次に，ステップ 1 の応力分布の元で，微 小時間 $\Delta t$ の損傷進展を解析する。すなおち, FEM 弾性 クリープ解析で求めた各結晶粒位置の応力に基づいて, 粒界に負荷される $F$ 扎よび $K$ を定め，各粒界の破壊抵抗 $R$ を $d R / d t=-(F+K a)$ ずつ減少させ， $R$ がゼロになった 粒界は微小欠陮になるとする。単位面積あたりの微小欠 陷の数（微小欠陥個数密度）を，その時刻でのクリープ 損傷の指標とする．この方法により，ステップ1の応力 分布の下での微小欠陷個数密度の時間変化，すなわち， 損傷の時間変化が得られる.

なお，一定荷重を受ける溶接継手 HAZ 細粒域の板厚 内部では，応力分布に起因してクリープ損傷分布が生じ る. 損傷力学による解析では，これに伴い，巨視的縦弾 性係数の低下や巨視的クリープひずみ速度の加速など， 材料特性の分布が生じ，このため応力分布が変化するこ とが考えられる。本報でも微小欠陷個数密度と巨視的剛 性の関係を求め，剛性低下による応力分布の変化を検討 したが，寿命末期を除いては，通常の弾性クリープ解析 で求まる応力分布を基に損傷進展を考えてよく，余寿命 評価に与える影響も小さいと判断された，従って，本報 での議論では，応力分布に対して，損傷進展による剛性 低下の影響は考慮していない

\section{4 実体溶接継手の損傷再現解析}

Fig. 5 にTable Iの条件 (3) の大型溶接継手クリープ 試験体を示す。これに対して，粒界破壊抵抗分布モデル と FEM 弾性クリープ解析を併用したクリープ損傷再現 解析を行った。

母材，溶金, HAZ 粗粒域および HAZ 細粒域の解析用

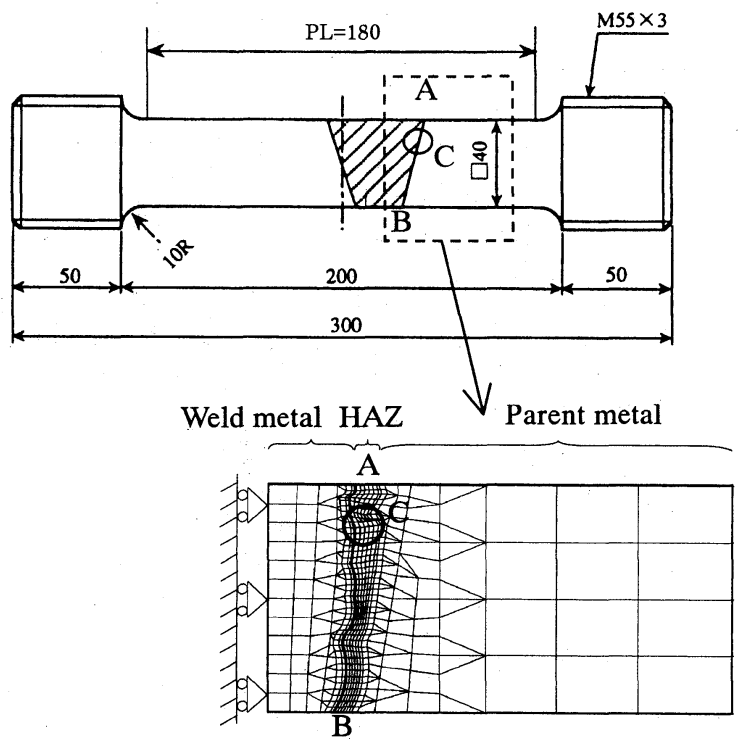

Fig. 5. Welded joint test specimen and FEM model. 
クリープ特性としては既報帛による值を用い，また，縦 弾性你数としては, 全材料について $126 \mathrm{GPa}$ 用いた。 Fig. 5 中に解析に用いた FEM モデルを併記する。試験 体の溶金中央部から右半分をモデル化している。解析プ ログラムとしてはSENSOR/NSASを，また，要素とし ては 8 節点アイソパラメトリック要素を用い, 平面応力 条件で構造定常状態となるまで解析を行った，解析によ り得られた構造的定常状態 (2000h 後) での HAZ 細粒 域（AB ライン）の応力分布老 Fig. 6に示す。最大主応 力（負荷軸方向応力が主体）拉よびvon Misesの相当 応力を示している. 弾性状態では縦弾性係数は共通であ るため, FEM モデル上で応力は一様であるが，クリープ 状態になると母材, 溶金, HAZ 粗粒および細粒域のクリ 一プ速度の違いにより, 板厚方向に応力分布が生じてい ることがわかる。最大主応力, von Misesの相当応力と も, 試験体の上下表面に比べて板厚内部が大きいが, von Misesの相当応力の分布は最大主応力に比較すると 平坦である、クリープ損傷を評価する応力としては，実
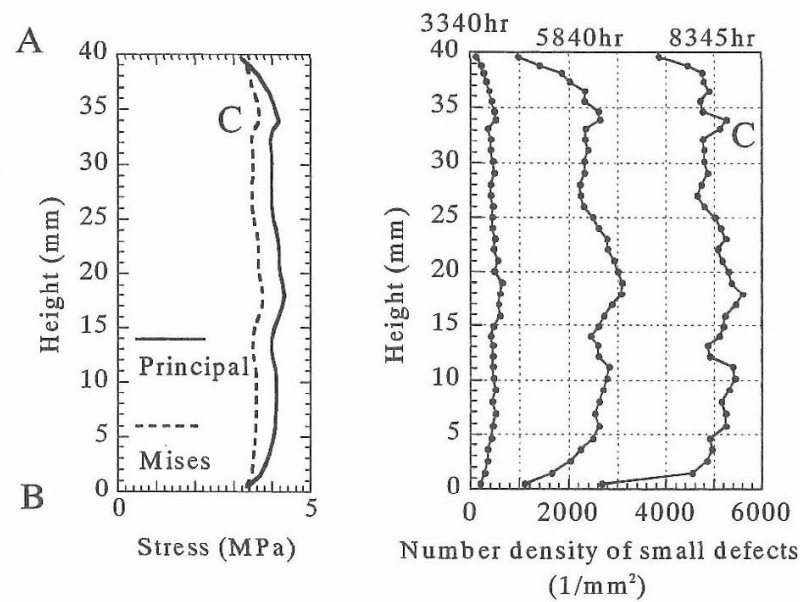

Fig. 6. Simulation results of welded joint test specimen.
験的検証 ${ }^{15)}$ が進められているが，通常，最大主応力㭊る いはvon Misesの相当応力を用いることが多い.ここで は，粒界クリープ破壊は静水圧の影響を受けるため最大 主応力による評価が適していると考帛, ${ }^{9}$ 粒界破偯抵抗分 布モデルの結晶粒界に垂直方向の最大主応力を用いた。

この応力分布に従い，前章で示したクリープ損傷再現 解析を行った結果を Fig. 6 中に併記する。解析により得 られた $t=3340 \mathrm{~h}, 5840 \mathrm{~h}$ および試験終了時の $8345 \mathrm{~h}$ で の微小久樎個数密度の分布は, Fig. 6 中の主応力分布と 対応した分布形状であり，時間の経過とともに，増加し ていく様子がわかる. Fig. 5 中の損傷の大きい部位 C 点 （上面から約 $6 \mathrm{~mm}$, 応力極大点）について, 微小欠陷個 数密度の時刻変化を計測結果と併せて Fig. 7 に示すが, 別途実施した計測結果とほぼ一致している。な拉,ここ での微小欠陥個数密度は, 例えば 5 個の結晶粒界での微 小久陥が合体している場合，5 と数える方法を用いてい る。また，この部位の微小久陷の分布について，再現解 析によるものと，実測による拡大写真を対比して図中に 示しているが, 実際の微小久陌分布, 寸なわち, 合体し た微小欠陷の数や長さのばらつきを含㐫てほぼ再現でき ることがわかる。

参考までに, 微小欠陥の発生駆動力のみを考光, 成長 駆動力を無視した結果も Fig. 7 に併記している。寿命末 期では, 発生駆動力のみを考光た結果は, 成長駆動力も 考慮した結果より，19\%程度低目の推定となっている。 な扔, 寿命の $85 \%$ 程度の時点である $7200 \mathrm{~h} に$ 打いて, 目 視観察されたさ裂状欠陌長さの最大值は $3.8 \mathrm{~mm}$ であり， 一方, 発生招よび成長駆動力の両者を考学た解析予測值 は $2.3 \mathrm{~mm}$, また, 発生の及を考慮した解析予測值は $0.3 \mathrm{~mm}$ であった。この点からも，本報での発生および成 長駆動力の仮定はほぼ妥当であったと考气られる。

板厚 $40 \mathrm{~mm}$ にまたがる1列の粒界モデルに発生した全 ての微小欠宿の長さを合計し，これを 30 列の粒界モデ
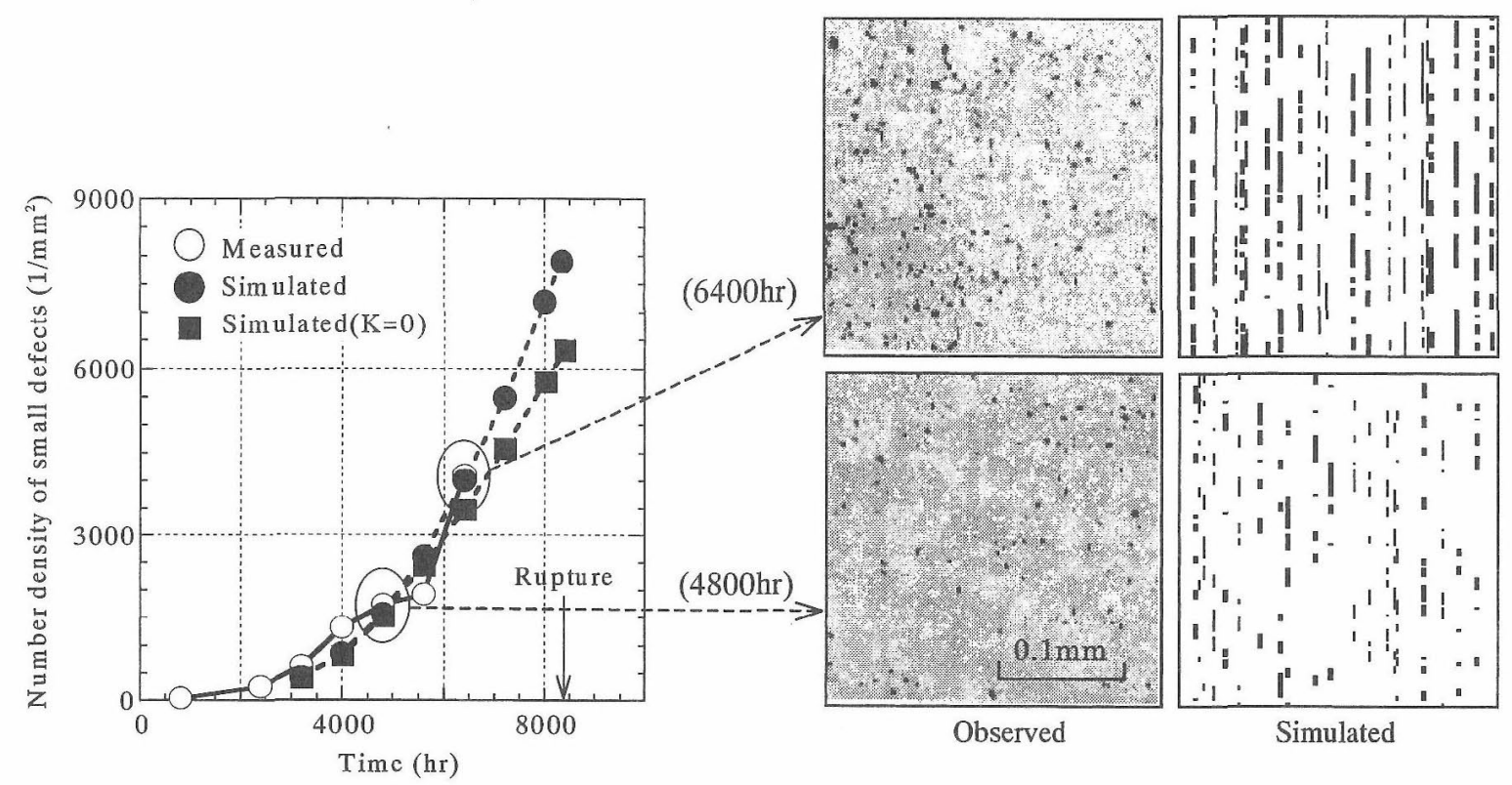

Fig. 7. Estimation of number density of small defects (Point C). 


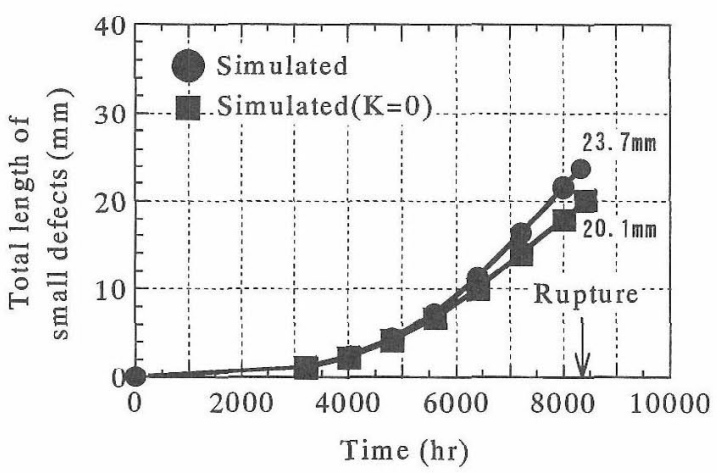

Fig. 8. Simulated total length of small defects.

ルで平均した合計欠陷長さの平均值を Fig. 8 に示す。破 断直前（試験時間約 8400 時間）では，合計欠陷長さの 平均值は約 $25 \mathrm{~mm}$ であり，板厚 $40 \mathrm{~mm}$ の 6 割であった。 参考までに，成長駆動力を無視した場合の結果も併記し ているが，18\% 程度低めの值であった。

実際の大径配管に本報でのクリープ損傷再現解析を適 用した例として, Table Iの条件 (2) で示したPlant B の主蒸気配管エルボ長手溶手部の損傷解析を実施した。 Fig. 9 に，切断面写真，FEM 要素分割図，構造的定常 クリープでの応力解析結果, 扣よび, 微小欠陷個数密度 の分布の再現解析結果と計測結果を対比して示す。

抜管された材料の溶接部学切断し, HAZ 細粒域の微小 久陷個数密度を調査した。Fig. 9 写真中の配管外表面に 達しているき裂状欠陷は，図中にDEで示す HAZ 細粒 域にあり，权厚内部加発生・成長している。溶金内部 のき裂状欠陥は，溶金中の多層溶接の HAZにある。 FEM 応力解析 ${ }^{8)}{ }^{10)}$ は，切断調査による溶接ビード形状 を再現して配管周断面の $1 / 4$ を 2 次元モデル化し, 平面 ひずみ条件で実施した。解析に用いたプログラムおよび 要素は上記と同様であり，解析用クリープ变形特性とし

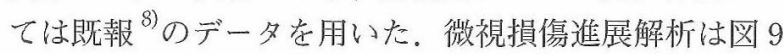
中に DEで示した HAZ 細粒域について実施した。溶接 継手の場合と同様に，配管外面から内面まで，FEM 要 素にまたがる粒界モデルを 30 列作製した。温度と FEM
解析により推定した応力に従って, 各 FEM 要素中の $F$, $K$ を定め，己れにより各粒界の破壊抵抗 $R$ を減少させた。 本解析により求めた微小久㫟個数密度の板厚断面上での 分布は, 計測結果とほぼ一致した。

\section{5 実機への適用方法について}

前章で示した解析方法は溶接ビード形状を含む全ての データが揃った場合の損傷評価手順を示しており，検証 結果についても板厚方向のビード形状が既知の場合につ いて解析結果と実測結果の対比を示し, 粒界破壞抵抗分 布モデルと FEM 弾性クリープ解析を組み合わせた損傷 評価方法の適用性を示した。この方法により，板厚内部 のビード形状などを既知とすると，外径・板厚などの配 管形状や温度・压力などの運転条件, あるいは運転条件 の変化などに対して, 外表面と板厚内部の損傷度の対応 関係などについての解析予測が可能となり，実用的にも 有効と考学られる。

一方, 個々のプラントや配管部位の損傷度予測への適 用については課題が残る。すなわち, 板厚内部の溶接ビ 一ド形状は不明であり，また，検査結果については，運 転中の所定の時刻, あるいは複数の時刻での, 外表面で の微小久陷個数密度と, 板厚内部における裂状欠陷の 板厚方向の長さが与えられており，板厚内部の詳細な損 損傷分布は不明である。

板厚内部の応力分布の一般的傾向については, $30 \mathrm{~mm}$ 程度の薄肉から $100 \mathrm{~mm}$ を越える厚肉配管に関して異な るビード形状を含を複数の溶接部断面形状の弾性クリー プ解析結果が報告 ${ }^{9)}$ されており，以下のことがわかって いる。すなわち, Fig. 9 に厚肉の長手溶接についての応 力分布の一例が示されているが，このような長手溶接部 については下記の知見が示されている。

（1）内表面に比べて, 外表面の応力が高く, 最大応力 点は外表面から 5 - 10 mm 程度の位置にある。

(2)この最大応力点の応力は, 外表面の応力に対し て, 5一 30\%高めの值となる。これは, 薄肉, 厚肉など の配管形状とビード形状のばらつきが映されたもので ある。

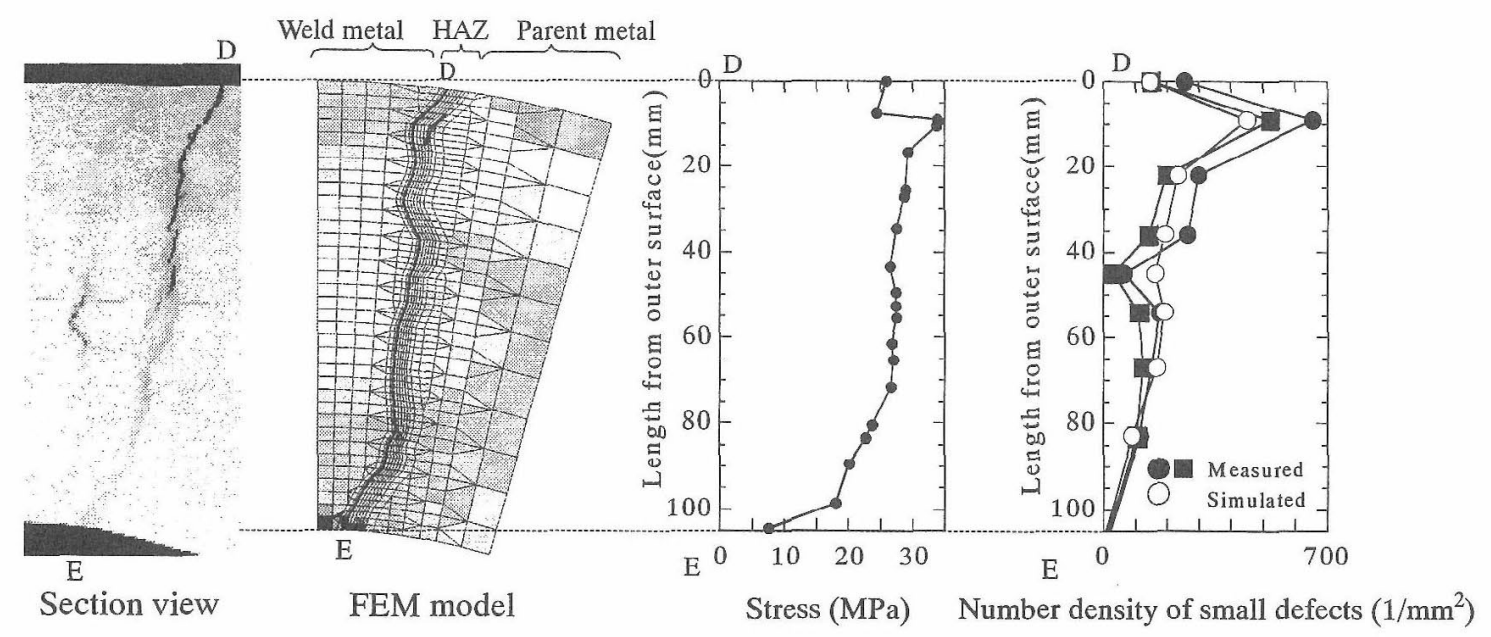

Fig. 9. Simulation results of plant B. 
（3）厚肉の場合は，外面から内面にかけての板厚内の 平均的な応力勾配が大きいのに対して, 薄肉の場合は, この平均的な応力勾配が小さく平坦な応力分布となる.

個々のプラントや配管部位に対して, 板厚方向におけ る篇密な応力分布予測は困難であるが, 上記 (1) (3) 項の知見も生かして, 板厚方向に打ける応力分布や, こ れに基づく損傷分布を実用的に推定する方法も考えられ る.すなわち，

（1）考えられる種々の代表的なビード形状を仮定し て，設計温度・圧力に対する弾性クリープ解析を行う。

(2) 厚断面上での平均的な応力分布を求めるととも に，断面上の各場所における応力值のばらつきを定量的 に検討する。

（3）まず，この平均的な応力分布で損傷解析シミュレ ーションを開始する.

（4）配管溶接部の外表面あるいは板厚内部の非破壊検 查結果が得られた時点で, 外表面抢よび板厚内部の欠陥 検出部での欠陥発生・成長駆動力を修正する。併せて, この修正に対する欠陥検出部の応力値の変動が (2) 項で 求められたばらつきの範囲にあることを確認する。 また， 板厚全体の全ての箇所にわたって欠樎検出箇所と同じ比 率で欠陥発生・成長駆動力を修正する。

（5）非破壞検査の結果が得られる度 (4) 項の過程を繰 り返す。

この方法は, 一つの案であり, また, 検查結果にもば らつきがあるため, 実機配管損傷の断面調査との比較例 の蓄積が望まれる. また, 粒界破壊抵抗分布モデルの材 料特性決定も含めて, 他材料への適用法の検討なども必 要と考元られる。 なお, 損傷予測の観点からは, 板厚内 部の損傷の非破壊検查法高度化が重要であることは言う までもなく，フェイズドアレイ法 ${ }^{16)}$ 他の方法の実用化が 望まれる。

$$
6 \text { おわりに }
$$

21/4Cr-1Mo 鋼で代表される低合金鋼製大径配管溶接 継手 HAZ 細粒域の多場所発生型クリープ損傷について, 本材料の損傷形態と応力依存性を考虑した粒界破壊抵抗 分布モデルの材料特性を設定するとともに, FEM 弾性 クリープ解析と組み合わせることで, 微小久樎個数密度 で表される溶接継手板厚内部のクリープ損傷分布を定量 化する手法を提案した。提案した手法を大型溶接継手ク リープ試験や実機使用材に適用した結果, 計測結果とよ
く対応するする微小欠陥個数密度の推定ができることが わかった。

\section{参 考 文 献}

1) F. V. Ellis, R. Viswanathan, ASME-PVP, 380, 59 (1998).

2) 周正, 大谷隆一, 北村隆行, 多田直哉, 小阪 晃, 材料, 44, 78 (1995).

3) 時吉 巧, 山内雅文, 西村宣彦, 橋本貴雄, 今本敏彦, 三菱重工技報，38，84（2001）。

4) 今本敏彦, 藤田正昭, 橋本貴雄, 若林嘉幸, 岩本啓一, 西村宣彦, 火力原子力発電, 51-8，14（2000）.

5) 多田直哉, 北村隆行, 大谷隆一, 日本機械学会論文集, A-56, 708 (1990).

6) N. Tada and R. Ohtani, "IUTAM Symposium on Creep in Structure", p.75 (2001) KLUWER ACADEMIC PUBLISHERS.

7）西田秀高, 由 上勤, 渡邊 肇, 山内雅文, 時吉 巧, 藤田正昭，日本機械学会論文集，A-66，946（2000）。

8）田中保幸, 山内雅文, 菅沢光彦, 日本材料学会第 33 回高 温強度シンポジウム前刷集，70（1995）。

9）中馬康晴, 山内雅文, 藤田正昭, 椎橋 啓, 日本機械学 会熊本地方講演会論文集，47（2001）。

10）山内雅文，西村宣彦，增山不二光；菅沢光彦，日本材料 学会第 33 回高温強度シンポジウム前刷集, 65 (1995).

11）多田直哉，飯尾真司，北村隆行，大谷隆一，材料，41, 1165 (1992).

12) C. F. Shih and J. W. Hutchinson, Trans. of ASME Journal of Engineering Materials and Technology, 98, 289 (1976).

13) M. Yamauchi, Y. Chuman, N. Nishimura and F. Masuyama, IMechE Conf. Trans. Sixth Int. On Creep and Fatigue-Design and Life Assessment at High Temperature, 511 (1996).

14) R. Viswanathan, 増山不二光, 丸山公一訳, “高温機器部 品の損傷メカニズムと寿命評価”，第 3 章（1993）日刊工 業新聞社.

15) M. Sakane and T. Hosokawa, "IUTAM Symposium on Creep in Structure", p.411 (2001) KLUWER ACADEMIC PUBLISHER.

16) L. D. Nottingham, H. E. Queen, Proc. EPRI/DOE Conf. in Life Assessment and Optimizartion of Fossil Power Plants, Session A (2002). 